\title{
診断及び治 療
}

\section{頸椎前彎による蕕下障碍の症例}

山口医科大学耳鼻咽喉科呚室

本 庶 正 一

\section{1 序}

燕下障碍の原因は、複雜多岐である。最近私共

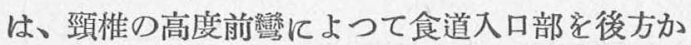
ら压迫し、そのために强度の罴下障碍を起した症 例を経驗したので報告する。

\section{2 症 例}

1) 患者は 43 才の男。炭抗の抗内夫。主派は高度の镘 下障碍（與下不能）。家族歷は同胞 11 名の中、3名加 肺結核症で死ししている。子 3 名健在, 癌、神経症及び 精神病の家族歷はない。既往症は生来健康であつたが。 16 才の時に誘因き考えられるものなく、顕が炎第に腫 れて来て、そのために頸の運動が妨げられケ。内科医に 医療を受け、3カ年で漸次頸の腫脤は無くなつケが、頸 の運動障碍は瘾らないま、に現在に至つている。しかし それに因る器下障碍はなく、食事には決して不自由はな

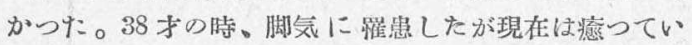
ろ。その他著患はない。

\section{2) 現病歷。}

昭和 25 年 2 月 28 日の早朝 4 時頃に。抗内で前かが

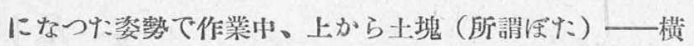
40 糎、积 20 糧、高さ 10 粯位—が落ちて、頸から肩 にかけて打撲をらけげ。その祭靕みは激しかつたか。意 識障碍は嘸がつた。同日 8 時頃。朝食の時「のご」に食 物がびつかいる樣でむつたが、普通食が通常の牛分位食

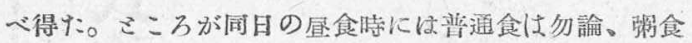

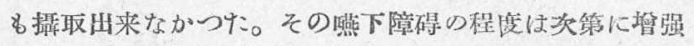
し流動食も與下困難となつた。值ちに勤務地の炭抗病院 に收容され、医治れ受けたが、嬹下障碍は軽快さず、攝 食不能に打ちいつた。同年3月3日紹介されて私共の外

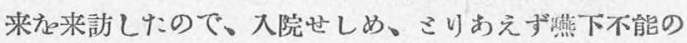
原因を磪認するケほ諸検查を行い。炎いで適磪な療法か 実施するここにした。

\section{3) 現 症。}

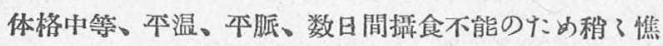
悴している。胸腹部諸臟器、及び四肢に渚変はない。

\section{三 宅 清 美}

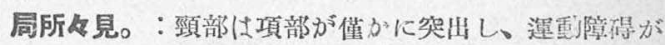
認められる（前頸 37 度後頸 35 度。右施 45 度。左施 38 度）が。外表に創傷はなく、発発赤腫脤もない。壦下運 動て啹頭は良く举上する。口腔さ口蓋軎が僅がに左偏し ている。喉頭鏡検查ては下咽頭、舌根部に罢甞はなく。 犊頭內腔は頚部の運動障碍のために明視出来ない。メ。 直洼鏡娭查を行い。食道、唤頭及ど気管え゙精查しようる

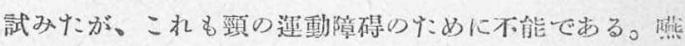

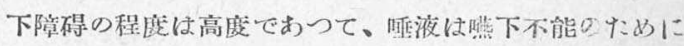
ホえす゚ロ腔內に溜り。約 5 分閒每に唾营に昩き出ててい

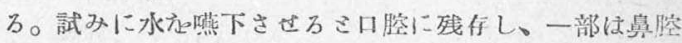

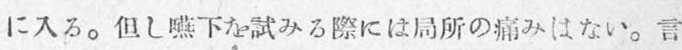

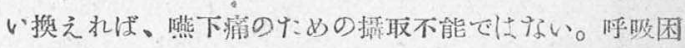

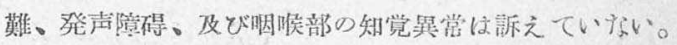

局所の X 線写真所見々次の如くでまる。

(附図参照)。

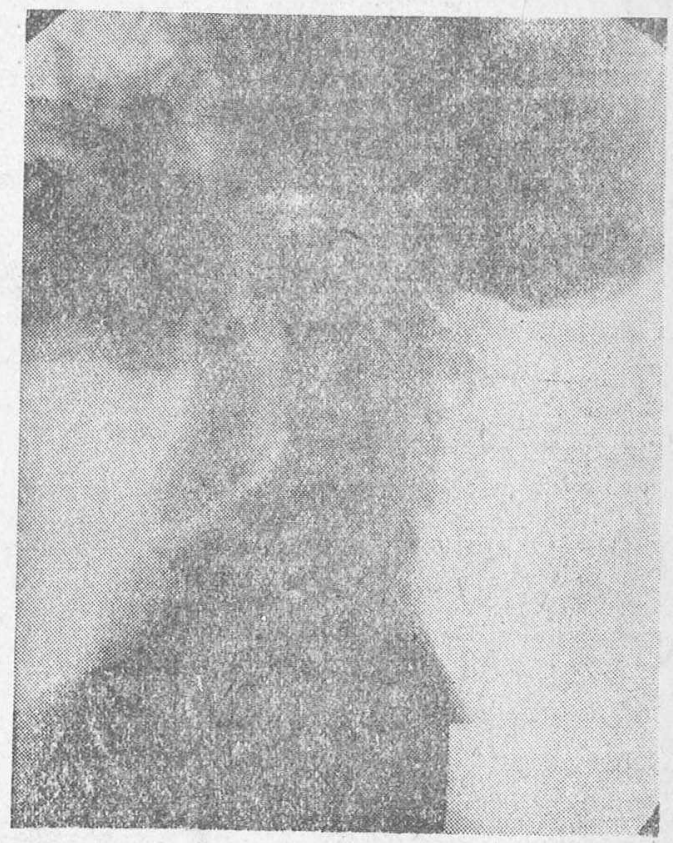

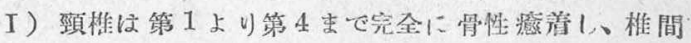


軟骨わ全く久き、瑰状椎形成か呈し、この部に著しい後 彎が見られる。第 5 頸椎以下は溗着なく、椎間軟骨る存 在していろが、上部の後彎に対㢃して著しい前彎があ り、しか子第 5、6 頸椎が最も前方に突出わり、正常に比 してこの部の椎体間の距離は大こなり、洓哭起閒の距離 は小るなつている。

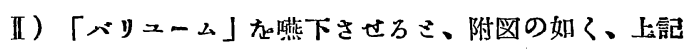
第 5 頸椎の最も前方に突き出げ部位で狭窄があるけめに 停溜し以下に流下しない。

抄神経を検查したが、全て著変は認のられない。㝴䐋 注スによつて流動食良攝取させるこさが出来る。

\section{4）治療及び泾過。}

平熟に-経過し、局所の疼痛方訴えず、しかも急激に高

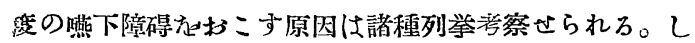
かし本例では、1）哭下障碍をおこす前には頸部の外傷 か受けている。2）前訅の如く頚椎に変形があり、その

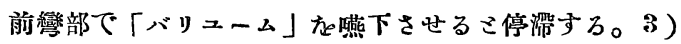
脳神経に著変がないきいら事実から食道入口部、及びそ

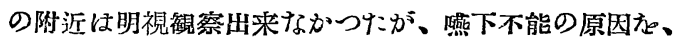
頸椎の前彎によつて食道入口部え後方から圧迫している

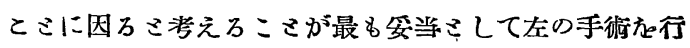
つた。左胸鎻乳樣筋の前辺に沿つて皮切し、食道の左側 壁に達してその周囲れ広く剥離し、さくに食道の後壁わ 完全に、更に右側も剥離した。術野は、視钐上椎体の前 方突出があるのみで、他に食道方圧迫しているものはな い。次いで右示指な挿入して、食道壁、及びその周围方 精しく触钐精查したが、食道内部には異常なく、前方で は輸状軟骨には変化はなく、側方にも变化は認められず 只椎体の前方突出があろのみである。しかし椎体の突出 の程度は後方より食道譬方圧迫してはいらが、これによ つて本例に表われろ樣な高度の舆下障碍が著き起される そは思われないので、試みに「バリューム」を嬹下させ

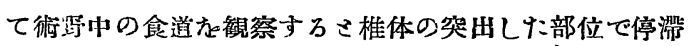
する。そこで頸椎の第5、6の椎体す露出し、整でその突 出した前面の一部分九制万き共に骨鈿子て除去し、椎間

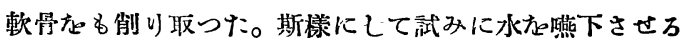

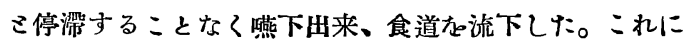
力か得て更に椎体の前彎突出している部分え例り取り、 手術方終えた。なお㭪野で明視出来万範囲では迷走神経 には買常なかつた。

術後経過は良好て、本温に経過した。嬩下障碍は軽快 し、手䢖の柆日には重湯卡。更に一䓢間後には普通食

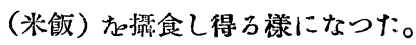

\section{3 考按}

嚥下障碍す原因は多種多樣であるが、これまで

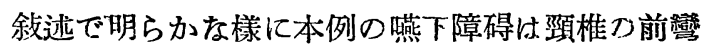
によつて食道入口部究圧迫したことに因るもので ある。

食道入口部を、その周囲から压迫して生する鱟 下障碍は稀であつて、数的にはすべての食道狄窄 の中、僅かに約 $2 \%$ 占め（Guisez）、その原因 は 1) 輪狀軟骨の骨化、2) 頸椎の前彎、3) 甲 狀腺腫、4) 喉頭の腫瘍、5) 梦巴腺の腫脹 等で ある。

文献によれば、この中 2 )の頸椎の前彎は胸 椎の後彎による代償性の前彎によつて來るとのみ 記載されている。してみれば、本例の樣な頸椎上 の後彎による代償性の前彎は稀なのであろ5。

本例における頸椎の変形は、その X 線写眞像 から判断すると骨変化は、陳旧性である。これは 本例の 䠶往症の項で前述したように、16才の頃 に頸部腫脹を生じ、約 3 力年を経て頸部の運動障 碍を貽し治癒しているが、そのときに惹起したる ので、恐らく頸椎「カリェス」の後胎的変化であ ろ5。

さて本例におてつた讌下障碍の原因は、この樣 な頸椎前彎が、食道入口部を後方から圧迫してい たが、鱟下障碍をおてす程度でなかつたので何等 嚥下障碍をおてすととなく経過したが、偶了頸部 て打撲を受けたてとによつて、その前彎の程度を 增强し、食道入口部を压迫する程度を强め、苝下 障碍をおてしたと考えられる。

郎ち、頸椎「カリエス」による後胎症として頸 椎前彎がおてり、てれがために食道入口部を後方 より臣迫して與下障碍をおてす、所謂準備狀態に あつをものが頸椎前彎の度を高め、强く食道入口 部を圧迫して嚥下障碍を惹起したものと思われ る。

\section{4 結 び}

43 才の男子で、頸椎の高度の前彎によつて食 道入口部を後方から圧迫し、器下不能をおてした 症例を手術的に前彎前方二突出した椎体を除去す ることによつて鱟下不能を治瘾せしめ得た。 